http://dx.doi.org/10.1590/0370-44672015680040

\begin{abstract}
Renato de Mendonça
Doutor em Engenharia de Materiais

Bolsista/Pesquisador

Universidade Federal de Alfenas, Instituto de Ciência e Tecnologia

Poços de Caldas - Minas Gerais - Brazil

rmendonca20@gmail.com
\end{abstract}

\section{Neide Aparecida Mariano}

Doutora em Engenharia Metalúrgica

Docente/Pesquisadora

Instituto de Ciência e Tecnologia

Poços de Caldas - Minas Gerais - Brazil

neideaparecidamariano@gmail.com
Universidade Federal de Alfenas,

\section{Tempering effect on the localized corrosion of $13 \mathrm{Cr} 4 \mathrm{Ni0.02C}$ and 13Cr1 Ni0.15C steels in a synthetic marine environment}

\author{
Efeito do revenido na corrosão localizada \\ dos aços 13Cr4Ni0.02C e 13Cr1 Ni0.15C \\ em ambiente marinho sintético
}

\begin{abstract}
Primarily, tempering is used in martensitic stainless steels with low carbon in order to change their mechanical properties. However, it also modifies the corrosion properties; usually depending on the temperature and duration of the heat treatment. This work investigated the impact of tempering on the corrosion of $13 \mathrm{Cr} 4 \mathrm{Ni} 0.02 \mathrm{C}$ and $13 \mathrm{Cr} 1 \mathrm{Ni} 0.15 \mathrm{C}$ (\% weight) steels. Samples were tempered at $650^{\circ}, 700^{\circ}$ and $750^{\circ} \mathrm{C}$, characterized by optical microscopy and cyclic anodic polarization tests in a synthetic marine environment. The results showed differences in the microstructure of the $13 \mathrm{Cr} 4 \mathrm{Ni} 0.02 \mathrm{C}$ tempered samples, which changed from lath to lamellar with precipitates in the prior austenite grain boundaries. On the other hand, tempering did not affect the $13 \mathrm{Cr} 1 \mathrm{Ni} 0.15 \mathrm{C}$ microstructure. The anodic polarization tests showed that the pitting potential of the $13 \mathrm{Cr} 4 \mathrm{Ni} 0.02 \mathrm{C}$ samples decreased with the tempering temperature increasing. Similar values of pitting potential were found with the $13 \mathrm{Cr} 1 \mathrm{Ni} 0.15 \mathrm{C}$ tempered samples, which were lower than the $13 \mathrm{Cr} 4 \mathrm{Ni} 0.02 \mathrm{C}$ samples after tempering. It shows that even though the corrosion resistance of the $13 \mathrm{Cr} 4 \mathrm{Ni} 0.02 \mathrm{C}$ reduces when the tempering temperature was increased, it is better than that presented by $13 \mathrm{Cr} 1 \mathrm{Ni} 0.15 \mathrm{C}$.
\end{abstract}

Keywords: corrosion, marine environment, martensite, polarization tests.

\section{Introduction}

Martensitic stainless steels with low carbon concentration have been employed in hydraulic turbines, pumps and high pressure pipes in the energy and petrochemical industries (Song et al., 2010; Bilmes et al., 2001; Wang et al., 2010; Zhang et al., 2005). Usually, they are exposed to environments where the corrosion and cavitationerosion resistances are important properties (Wang et al., 2010; Gervasi et al., 2011; Lai et al., 2012). In the chemical composition of these steels, the chro- mium is for increasing the corrosion resistance and the nickel, for stabilizing austenite and inhibiting delta ferrite $(\delta)$, the formation of which increases brittleness (Liu et al., 2010; Balan et al., 1998; Dawood et al., 2004; Calliari et al., 2008; Ma et al., 2012).

Tempering treatments are often used to change the toughness and brittleness of this family of steels. It also modifies the microstructure. Observed alterations include a reduction in the dislocation density created during quench- ing, microstructural transformations and nucleation of new phases or compounds (Mendonça et al., 2014; Calliari et al., 2008; Ma et al., 2012; Park et al., 2007; Choi et al., 2007). Commonly, tempering also incurs the formation of chromium carbides, such as $\mathrm{Cr}_{23} \mathrm{C}$, which have deleterious effects on the corrosion properties (Qin et al., 2008; Sedriks et al., 1996; Dexter, 2006).

The study of corrosion in a marine environment is particularly interesting for these steels because they are used in 
offshore oil production facilities (Mariano et al., 2007). The marine environment is complex because of the wide variety of chemical compositions, dependent on both, the geographic position and the depth. For instance, the literature (Dexter, 2006; Griffin, 2006) reports variable concentration of chlorides in marine water, which is significant because chlo- rides increase the degradation processes of stainless steels by localized corrosion.

The influence of tempering lowcarbon stainless steels on the corrosion resistance in marine environments is not well-understood, even though the importance of these steels and the microstructural transformations observed after heat treatments are well-known (Calliari et al., 2008; Ma et al., 2012; Bilmes et al., 2001; Wang et al., 2010). This paper presents a study that uses cyclic potentiodynamic polarization tests in a synthetic marine environment to investigate and compare the effect of tempering on corrosion for two steels with different nickel and carbon concentrations: 13Cr4Ni0.02C and 13Cr1Ni0.15C.

\section{Methods}

The steels were produced in an electric arc furnace with argonoxygen decarburization (AOD). The chemical composition of the steels

\begin{tabular}{c|c|c|c|c|c|c} 
Sample & $\% \mathrm{C}$ & \%Si & \%Mn & $\% \mathrm{Cr}$ & $\% \mathrm{Ni}$ & $\% \mathrm{Mo}$ \\
\hline $13 \mathrm{Cr} 4 \mathrm{Ni0.02C}$ & 0.025 & 1.000 & 0.700 & 13.000 & 4.120 & 0.720 \\
\hline $13 \mathrm{Cr} 1 \mathrm{Ni0.15C}$ & 0.153 & 1.020 & 0.750 & 13.000 & 1.030 & 0.080 \\
\hline
\end{tabular}

The microstructure of the tempered samples was characterized using optical microscopy, and surface etching was achieved with modified Behara $\left(0.2 \mathrm{l} / \mathrm{HCl}+11 / \mathrm{H}_{2} \mathrm{O}+1 \mathrm{~g} / \mathrm{K}_{2} \mathrm{~S}_{2} \mathrm{O}_{3}\right)$ at room temperature.

Corrosion behavior was evaluated using a replicated electrochemical cyclic potentiodynamic polarization method. The electrodes were produced from stainless steel sheets, machined in

cylindrical forms (base area: $0.5 \mathrm{~cm}^{2}$ ), insulated with a slow-cure epoxy resin to prevent the formation of air bubbles at the resin-metal interface.

In preparation for the tests, all samples were polished mechanically with grade $600 \mathrm{SiC}$ sandpaper, rinsed in alcohol and dried. Two measurements were taken at room temperature $\left(25^{\circ} \mathrm{C}\right)$ for each sample with a model Autolab/PGSTART302 potentiostat-

\begin{tabular}{c|c} 
Compound & Concentration, g/L \\
\hline $\mathrm{NaCl}$ & 24.530 \\
\hline $\mathrm{MgCl}_{2}$ & 5.200 \\
\hline $\mathrm{Na}_{2} \mathrm{SO}_{4}$ & 4.090 \\
\hline $\mathrm{CaCl}_{2}$ & 1.160 \\
\hline $\mathrm{KCl}$ & 0.695 \\
\hline $\mathrm{NaHCO}_{3}$ & 0.201 \\
\hline $\mathrm{KBr}_{3}$ & 0.101 \\
\hline $\mathrm{H}_{3} \mathrm{BO}_{3}$ & 0.027 \\
\hline $\mathrm{SrCl}_{2}$ & 0.025 \\
\hline $\mathrm{NaF}$ & 0.003 \\
\hline
\end{tabular}

200FM) already at the tempering temperature $\left(650,700\right.$ and $750^{\circ} \mathrm{C}$ ) and removed 1 hour later to be cooled in air.
Table 1

Chemical composition of the samples (wt \%).

galvanostat device, using a conventional three-electrode cell. A saturated calomel electrode (SCE) was used as a reference electrode for the tests, while a Pt plate was employed as counter-electrode. The potentiodynamic curves were measured at a potential scan rate of $1 \mathrm{mV} / \mathrm{s}$ in a synthetic seawater environment prepared according to ASTM D 1141. The standard chemical composition of the seawater is presented in Table 02 .
Table 2

Chemical composition of the synthetic seawater. 


\section{Results and discussion}

\subsection{Influence of tempering on the microstructure}

Figure 1 shows the microstructure of the tempered $13 \mathrm{Cr} 4 \mathrm{Ni} 0.02$ steel at three different temperatures. In the sample tempered at $650^{\circ} \mathrm{C}$ (Figure $\left.1(a, b)\right)$, the typical martensitic structure of lowcarbon steel with laths and the delta ferrite as previously found by Mariano et al. (2007) are observed. In the sample tempered at $700^{\circ} \mathrm{C}$, the matrix is similar to the one in the sample tempered at $650^{\circ} \mathrm{C}$,

Figure 1

Microstructure of the

$13 \mathrm{Cr} 4 \mathrm{Ni} 0.02 \mathrm{C}$ samples tempered at $650^{\circ} \mathrm{C}(\mathrm{a}, \mathrm{b}), 700^{\circ} \mathrm{C}(\mathrm{c}, \mathrm{d})$ and $750^{\circ} \mathrm{C}(\mathrm{e}, \mathrm{f})$.

By comparison, Figure 2 presents the microstructures of the $13 \mathrm{Cr} 1 \mathrm{Ni} 0.15 \mathrm{C}$ samples after tempering. The morphology observed is similar in all tempered samples: delta ferrite in a martensitic matrix is observed and there

Figure 2

Microstructure of the 13Cr1Ni0.15C samples tempered at $650^{\circ} \mathrm{C}(\mathrm{a}), 700^{\circ} \mathrm{C}(\mathrm{b})$ and $750^{\circ} \mathrm{C}$ (c). martensite laths and delta ferrite (Figure $1(c, d))$. On the other hand, the sample tempered at $750^{\circ} \mathrm{C}$ presented a different matrix, with a lamellar morphology, delta ferrite and precipitates in the prior austenite grain boundaries (Figure 1(e,f)). According to Bilmes et al. (2001) and Song et al. (2010), this latter microstructure, with austenite in the grain boundaries and lamellae, is the result of martensite decomposition, at temperatures slightly under the austenitization temperature by diffusion processes. Furthermore Bilmes et al. (2001) proposed that the tempered microstructure is composed of tempered martensite, carbides and austenite. Equations (1) and (2) represent the reaction where martensite could become austenite (1) and/or ferrite (2). Both equations also indicate carbides formation.

$\alpha^{\prime}$ (martensite) $\rightarrow \gamma$ (austenite) $+\mathrm{M}_{\mathrm{x}} \mathrm{C}_{\mathrm{y}}$ (carbides)

$\alpha^{\prime}$ (martensite) $\rightarrow \alpha$ (ferrite) $+\mathrm{M}_{\mathrm{x}} \mathrm{C}_{\mathrm{y}}$ (carbides)
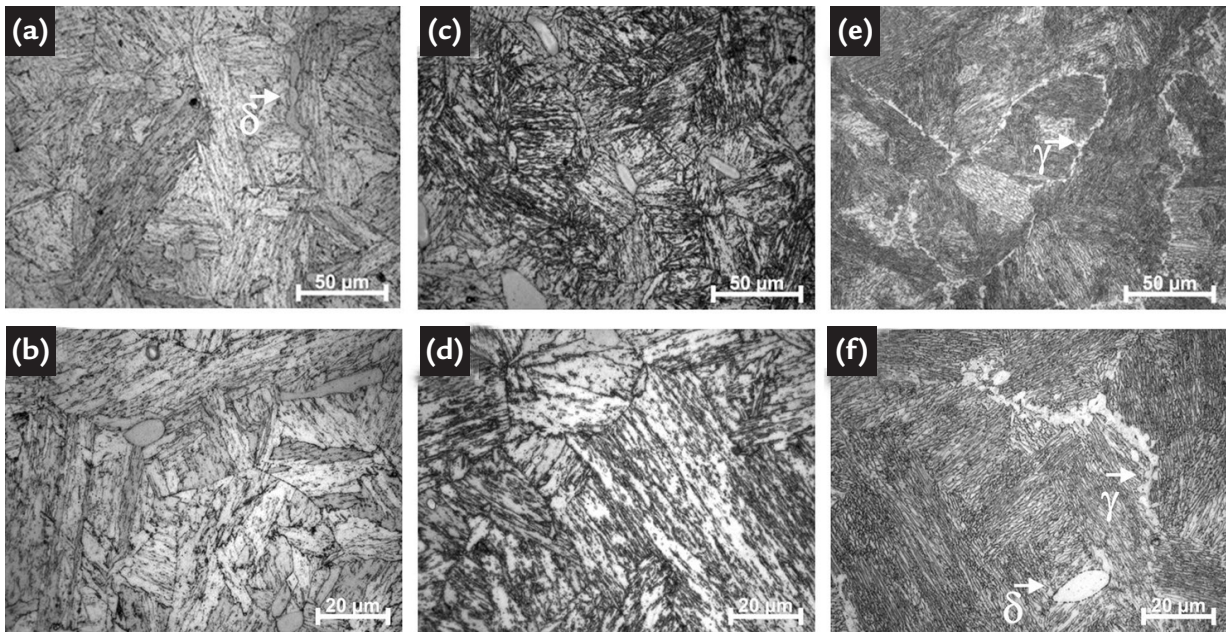

is no evidence of a tempering effect on the microstructure. The relatively low concentration of $\mathrm{Ni}$ is considered a crucial point in this result because it is the element employed to stabilize the austenite and is reported to facilitate reverse austenite formation in martensitic steel (Song et al., 2010; Bojack et al., 2012). Therefore, it is probable that the lower amount of $\mathrm{Ni}$ in the $13 \mathrm{Cr} 1 \mathrm{Ni} 0.15 \mathrm{C}$ samples would limit this steel's ability to present reverse austenite.
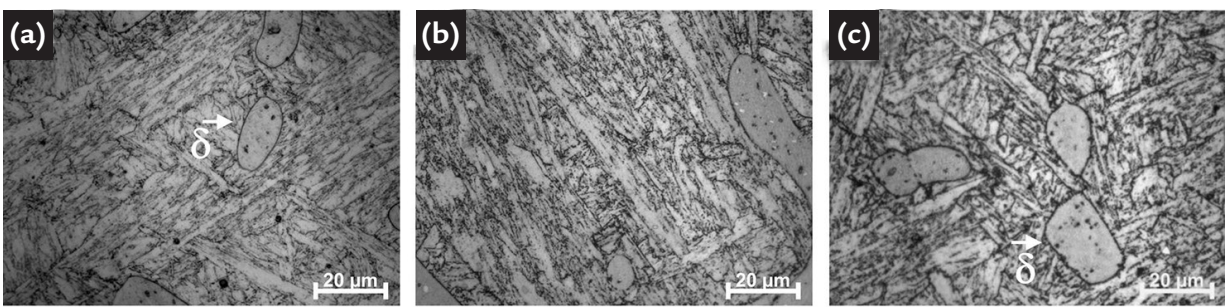

\subsection{Influence of tempering on cyclic anodic polarization curves}

Cyclic polarization curves are shown in Figure 3. The presence of closed cycles indicates pitting corrosion on the samples which were visually confirmed after the tests. Thompson and Payer (1998) discussed in details the cyclic anodic polarization curves and pointed out that, during reversion of the potential, active pits formed in the transpassive region can further increase the current density preventing the overlap of the points on the curve and providing the hysteresis loop. The curves show similar values for the corrosion potential $\left(\mathrm{E}_{\mathrm{CORR}}\right)$ - potential of a corroding surface in the electrolyte - and different values for the pitting potential $\left(\mathrm{E}_{\mathrm{PIT}}\right)$ - the lowest value of oxidizing potential at which pits nucleate and grow - as summarized in Table 3 and indicated in the Figure (3a).

The tempered $13 \mathrm{Cr} 4 \mathrm{Ni} 0.02 \mathrm{C}$ samples have similar $\mathrm{E}_{\mathrm{CORR}}$ values.
However, the results of $\mathrm{E}_{\mathrm{PIT}}$ are distinct; the highest value is from the sample tempered at $650^{\circ} \mathrm{C}$. The values of protection potential $\left(\mathrm{E}_{\mathrm{PROT}}\right)$ - the most noble potential where pitting corrosion will not propagate - show a significant difference for the sample tempered at $750^{\circ} \mathrm{C}$. This result indicates that the repassivation process on this surface is slower and consequently it is more susceptible to corrosion. In contrast, for the 
13Cr1Ni0.15C samples, the $\mathrm{E}_{\mathrm{PIT}}$ values are similar, and the instability of the current close to the $\mathrm{E}_{\mathrm{PIT}}$ (Figure 3 ) indicates the formation of metastable pits that are quickly passivated during the tests of the 13Cr1Ni0.15C samples. The $\mathrm{E}_{\text {PROT }}$ values
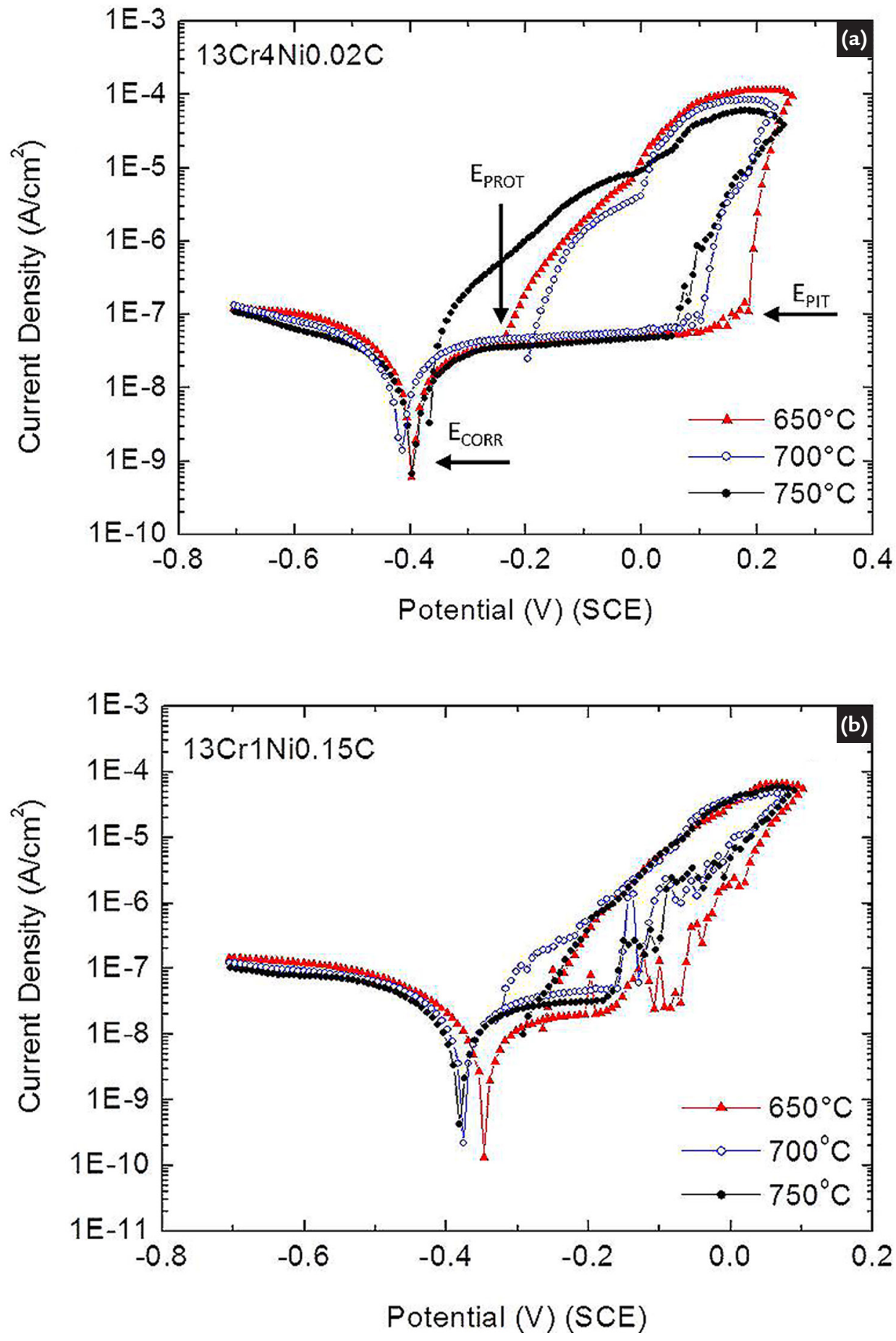

The different morphology exhibited by the $13 \mathrm{Cr} 4 \mathrm{Ni} 0.02 \mathrm{C}$ sample tempered at $750^{\circ} \mathrm{C}$ is related to its lower $\mathrm{E}_{\mathrm{PIT}}$ values and consequently to its low corrosion resistance. Influenced by high $\mathrm{Ni}$ concentration and characterized by the martensite changes, the phase transformations indicate the complex carbide formation in these steels that are associated with low corrosion resistance (Gervasi et al., 2011; Qin et al., 2008). Previous works (Song et al., can be considered similar because the spread is lower than $50 \mathrm{mV}$ (Thompson and Payer, 1998).
Figure 3

Cyclic anodic polarization curves for 13Cr4Ni0.02C (a) and 13Cr1Ni0.15C (b) after tempering at $650^{\circ}, 700^{\circ}$ and $750^{\circ} \mathrm{C}$.

precipitation, occur and change the corrosion resistance.

Comparative analysis of the cyclic polarization curves of the two tempered steels shows similar $\mathrm{E}_{\mathrm{CORR}}$ but a different $\mathrm{E}_{\mathrm{PIT}}$. Lower values of the pitting potential show that the $13 \mathrm{Cr} 1 \mathrm{Ni} 0.15 \mathrm{C}$ tempered steels are more susceptible to corrosion in marine environments. This susceptibility is mainly due to the molybdenum and carbon compositions: molybdenum plays a role in the growth 
of a stable passive oxide, preventing the pits formation; and carbon increases the propensity for the formation of chromium carbides related to the lower corrosion (Grubb et al., 2005). The

Table 3

Potential Corrosion $\left(\mathrm{E}_{\mathrm{CORR}}\right)$, Pitting Potential $\left(\mathrm{E}_{\mathrm{PIT}}\right)$ and Protection Potential $\left(\mathrm{E}_{\mathrm{PROT}}\right)$ obtained from the polarization curves.

\section{Conclusions}

In summary, the corrosion of tempered $13 \mathrm{Cr} 4 \mathrm{Ni} 0.02 \mathrm{C}$ and 13Cr1Ni0.15C steels was investigated by means of electrochemical cyclic potentiodynamic polarization in a synthetic marine environment.

Tempering at $750^{\circ} \mathrm{C}$ for 1 hour clearly modified the $13 \mathrm{Cr} 4 \mathrm{Ni} 0.02 \mathrm{C}$ steel microstructure. Typical martensitic microstructure constituted of laths became

\section{Acknowledgments}

The authors acknowledge the financial support of CAPES (Coordenação de

\section{References}

mechanism used to understand the carbide effect is connected with the affinity of chromium to carbon, producing chromium carbides and decreasing the amount of dissolved chromium, which is fundamental in passivation. The chromium carbide formation creates regions depleted in dissolved metallic chromium and consequently susceptible to localized corrosion.

\begin{tabular}{|c|c|c|c|c|c|c|}
\hline & $650^{\circ} \mathrm{C}$ & $700^{\circ} \mathrm{C}$ & $750^{\circ} \mathrm{C}$ & $650^{\circ} \mathrm{C}$ & $700^{\circ} \mathrm{C}$ & $750^{\circ} \mathrm{C}$ \\
\hline & \multicolumn{3}{|c|}{ 13Cr4Ni0.02C } & \multicolumn{3}{|c|}{ 13Cr1Ni0.15C } \\
\hline $\mathrm{E}_{\mathrm{CORR}}(\mathrm{mV}) \mathrm{SCE}$ & $-395.1 \pm 20.0$ & $-415.3 \pm 21.0$ & $-395.1 \pm 20.0$ & $-347.9 \pm 17.5$ & $-375.7 \pm 19.0$ & $-385.5 \pm 19.5$ \\
\hline $\mathrm{E}_{\mathrm{PT}}(\mathrm{mV}) \mathrm{SCE}$ & $189.0 \pm 10.0$ & $10.4 \pm 20.0$ & $5.0 \pm 15.0$ & $160.3 \pm 20.6$ & $157.9 \pm 16.0$ & $170.6 \pm 17.0$ \\
\hline$E_{\text {PROT }}(m V) S C E$ & -245.8 & -192.8 & -359.4 & -261.6 & -322.4 & - 277.5 \\
\hline
\end{tabular}

lamellar due to the nickel concentration that induces the formation of austenite. This lamellar microstructure of the $13 \mathrm{Cr} 4 \mathrm{Ni} 0.02 \mathrm{C}$ steel demonstrated lower pitting potential in marine environments and consequently reduced corrosion resistance.

On the other hand, the 13Cr1Ni0.15C steel did not present significant microstructural or changes in the pitting potential, and consequently in the corrosion resistance, with increasing of the tempering temperature.

The comparison of the pitting potential values of the two tempered steels shows that the corrosion resistance of $13 \mathrm{Cr} 4 \mathrm{Ni0} .02 \mathrm{C}$ steel is better than $13 \mathrm{Cr} 1 \mathrm{Ni} 0.15 \mathrm{C}$ steel, mainly due to difference in the carbon and molybdenum concentrations.
Aperfeiçoamento de Pessoal Ensino Superior) and the valuable comments of Mark
Vankeerberghen and Tamara Djikanovic from Belgian Nuclear Research Centre.

BALAN, K. P., VENUGOPAL, R. A., SARMA, D. S. Austenite precipitation during tempering in 16Cr-2Ni martensitic stainless steels. Scripta Materialia, v.39, p. 901-905, 1998.

BILMES, P. D., SOLARI, M., LIORENTE, C. L. Characteristics and effects of austenite resulting from tempering of $13 \mathrm{Cr}-\mathrm{NiMo}$ martensitic steel weld metals. Materials Characterization. v.46, p. 285-296, 2001.

BOJACK, A., ZHAO, L., MORRIS, P. F, SIETSMA, J. In-situ determination of austenite and martensite formation in $13 \mathrm{Cr} 6 \mathrm{Ni} 2 \mathrm{Mo}$ supermartensitic stainless steel. Materials Characterization, v.71, 77-86, 2012.

CALLIARI, I., ZANESCO, M., DABALÀ, M., BRUNELLI, K., RAMOUS, E. Investigation of microstructure and properties of a Ni-Mo martensitic stainless steel. Materials and Design, v.29, p. 246-250, 2008.

CAMIllo, A. P. C, ROVERE, C. A. D., AQUINO, J. M., KURI, S. E. Efeito do revenido na resistência à corrosão dos aços inoxidáveis supermatensíticos. Revista da Escola de Minas, v.63, p.117-122, 2010.

CHOI, Y-S, KIM, J-G, PARK, Y-S, PARK, J-Y. Austenitizing treatment influence on the electrochemical corrosion behavior of $0.3 \mathrm{C}-14 \mathrm{Cr}-3 \mathrm{Mo}$ martensitic stainless steel. Materials Letters, v.61, p.244-247, 2007.

DAWOOD, M. A., MAHALLAWAI, I. S. E., ABD EL AZIM, M. E., KOUSSY, M. R. 
Thermal aging of $16 \mathrm{Cr}-5 \mathrm{Ni}-1 \mathrm{Mo}$ stainless steel Part $1-$ microstructural analysis. Materials Science and Technology, v.40, p. 363-369, 2004.

DEXTER, S. C. Corrosion in seawater. In: CRAMER, S. D., COVINO Jr. B. S. Corrosion: environments and industries. Ohio: ASM Handbook, 2006. v.13C, p.2741. $1137 \mathrm{p}$.

GERVASI, C . A., MENDEZ, C. M., BILMES, P. D., LIORENTE, C. L. Analysis of the impact of alloy microstructural properties on passive films formed on low-C 13CrNiMo martensitic stainless steels. Materials Chemistry and Physics, v.126, p. 178-182, 2011.

GRIFFIN, R. B. Corrosion in marine atmospheres. In: CRAMER, S. D., COVINO Jr., B. S. Corrosion: environments and industries. Ohio: ASM Handbook, v.13C, 2006. 1137 p., p. 42-60.

GRUBB, J. F., DEBOLD, T. FRITZ, J. D. Corrosion of wrought stainless steels. In: CRAMER, S. D., COVINO Jr., B. S. Corrosion: materials. Ohio: ASM Handbook, 2006. v.13B, p.54-77. 703 p.

LAI, J. K. L. L., SHEK, C.H., HO LO CHSK. Stainless steels: an introduction and their recent developments. Benthan Science Publishers, 2012. 173p.

LIU, Y-R., YE, D., YONG, Q-L., SU, J., ZHAO, K-Y., WEN, J. Effect of heat treatment on microstructure and property of Cr13 supermartensitic stainless steel. Journal of iron and steel research international, v.18, p. 60-66, 2010.

MA, X. P., WANG, L. J., LIU, C. M., SUBRAMANIAN, S. V. Microstructure and properties of $13 \mathrm{Cr} 5 \mathrm{Ni} 1 \mathrm{Mo} 0.025 \mathrm{Nb} 0.09 \mathrm{~V} 0.06 \mathrm{~N}$ supermartensitic stainless steel. Materials Science and Engineering A, v.539, p.271-279, 2012.

MARIANO, N. A., PEREIRA, V. F., RODRIGUES, C. A. D., LORENZO, P. L., ROLLO, J. M. D. A. Caracterização da temperabilidade e das curvas de transformação de fases de aços inoxidáveis martensíticos do tipo FeCrN. Revista da Escola de Minas, v.60, p. 163-167, 2007.

MENDONÇA, R., ARDISSON, J. D., MELO, M. L. N. M., MARIANO, N. A. Study of the tempering effect in phase transformations of $13 \mathrm{Cr} 1 \mathrm{Ni} 0.15 \mathrm{C}$ and 13Cr2Ni0.1C steels. Materials Science Forum, v.775-776, p. 130-135, 2014.

PARK, J-Y., PARK, Y-S. The effects of heat treatment parameters on corrosion resistance and phase transformation of $14 \mathrm{Cr}-3 \mathrm{Mo}$ martensitic stainless steel. Materials Science and Engineering A, 449-451, p. 1131-1134, 2007.

QIN, B., WANG, Z. Y., SUN, Q. S. Effect of tempering temperature on properties of 00Cr16Ni5Mo stainless steel. Materials Characterization, v.59, p. 1096-1100, 2008.

SEDRIKS, A. J. Corrosion of Stainless Steels. New York: John Wiley e Sons, 1996. 437p.

SONG, Y. Y., LI, X. Y., RONG, L. J., PING, D. H., YIN, F. X., LI, Y. Y. Formation of the reversed austenite during intercritical tempering in a Fe- $13 \% \mathrm{Cr}-4 \% \mathrm{Ni}-\mathrm{Mo}$ martensitic stainless steel. Materials Letters, v.64, p.1411-1414, 2010.

TABATABAE, B. A., ASHRAFIZADEH, F., HASSANLI, A. M. Influence of retained austenite on the mechanical properties of low carbon martensitic stainless steel castings. ISIJ International, v.51, p.471-475, 2011.

THOMPSON, N. G., PAYER, J. H. DC Electrochemical Test Methods. Houston: NACE International, 1998. 124p.

WANG, P., LU, N. M., XIAO, N. M., LI, D. Z., LI, Y. Y. Effect of delta ferrite on impact properties of low carbon $13 \mathrm{Cr}-4 \mathrm{Ni}$ martensitic stainless steel. Materials Science and Engineering A, v.527, p. 3210-3216, 2010.

ZHANG, H., ZHAO, Y. L., JIANG, Z. D. Effects of temperature on the corrosion behavior of $13 \mathrm{Cr}$ martensitic stainless steel during exposure to $\mathrm{CO}_{2}$ and $\mathrm{Cl}$ - environment. Materials Letters, 59, p. 3370-3374, 2005.

Received: 13 March 2014 - Accepted: 07 April 2015. 